\title{
Motivations to seek electronic word of mouth communications and information adoption: development of a conceptual model
}

\author{
Daniele Doneddu ${ }^{1,2}$ \\ ${ }^{1}$ School of Management, Swansea University, Swansea SA1 8EN, UK \\ ${ }^{2}$ SCIENTIA group, Swansea, UK \\ d.doneddu@swansea.ac.uk
}

\begin{abstract}
Electronic word of mouth (eWOM) plays an important part in our everyday life. eWOM communications have been shown to affect the adoption of information, thus affecting the information seeker's decision-making. Identifying and studying how motivations to seek eWOM affect information adoption can prove beneficial in aiding new product, services and, in general, technology strategy development and adoption. This research aims at developing a model to investigate how certain specific motivations may affect the adoption of information sought through eWOM. This paper develops a set of hypotheses to help evaluate how motivations affect the information seeker's adoption of the information sought, based on the moderating effect of gender. The paper improves on the knowledge of factors affecting information adoption and the impact of gender, and thus help advance our understanding of consumer behaviour online and information processing. Future empirical research will test the proposed hypotheses to advance our understanding of the role of motivations when seeking eWOM information.
\end{abstract}

Keywords: electronic word of mouth, eWOM, information adoption, information seeking, motivations

\section{Introduction}

Consumers face difficulties when making online purchase decision due to limited information about the products/services provided by sellers [1]. Thus, more consumers use electronic word of mouth communications in their decision making process.

eWOM is defined by Ismagilova, Dwivedi, Slade and Williams [2] as "the dynamic and ongoing information exchange process between potential, actual or former consumers regarding a product, service, brand or company, which is available to a multitude of people and institutions via the Internet” (p.18). eWOM communications have significant impact on consumers and their behavior and it has received much attention from researchers. It was found that eWOM can affect individuals' information adoption $[3,4]$ which could influence attitude towards product or services [5, $6]$, intention to purchase $[7,8]$ and result in sales $[9,10]$. It is therefore important to 
investigate consequences and factors affecting information adoption, as it will advance understanding of consumer behaviour.

The majority of studies investigated factors affecting consumers' information adoption, such as source credibility [3] and quality [11] of the message, to name but a few. However, there is a lack of research and evidence of how motivations to receive eWOM communications can influence information adoption. Previous research found that motivations to receive eWOM can influence intention to buy, intention to engage in eWOM and frequency to platform visits [12]. Nevertheless, the influence of consumers' motivations - to receive eWOM - on information adoption has not been studies by previous research. It is important to know the factors affecting information adoption, as it will help advance the understanding of consumer behavior and serve marketers in their endeavors to develop strategies to influence consumers' purchase decision in turn influencing the level of sales. Thus, the aim of this research is to investigate how motivations to receive eWOM will influence information adoption by developing a conceptual model to advance the understanding of information processing.

The rest of the paper is structured as follows. Next section explores the key literature on information adoption and motivations to receive eWOM communication. The subsequent section introduces the conceptual model and presents the related hypotheses. Finally, the paper is concluded and directions for future research are outlined.

\section{Literature Review}

Information adoption is the extent to which people accept and use eWOM communication in making purchase decisions $[3,13]$. Studies on eWOM communications investigated that eWOM communications can influence information adoption [14-16]. Scholars identified different factors which can affect information adoption, such as source credibility, argument strength, information comprehensiveness, information consistency, quality, source attractiveness, homophily and valence [11, 15-18]. However, none of the studies investigated how motivations to seek eWOM communication can affect information adoption.

Researchers identified several main motivations for consumers to seek eWOM communications, such as risk reduction, social approval, reduction of search time and effort, getting product (usage) information and social interaction benefits [6, 19-21]. It was found by previous studies that motivations to receive eWOM communications affect consumer behaviour [12, 20], for example, consumers' intention to buy and communication behaviour resulting in frequency of platforms visits and number of comments.

Studies on eWOM communication call for further examination of the impact of motivations to receive eWOM communications on consumer's behaviour [20]. As a result, this paper focuses on the effect of specific motivations to receive eWOM communications on information adoption. This has not been researched before; shedding some light on the relationships investigated will help to enhance the theory of information processing. 


\section{Development of the Conceptual model}

This section introduces and discusses each of the constructs of the proposed research model. The proposed conceptual model is based on Hennig-Thurau, Walsh and Walsh [20] framework of motivations to receive eWOM and proposes that motivations influence information adoption and are moderated by gender.

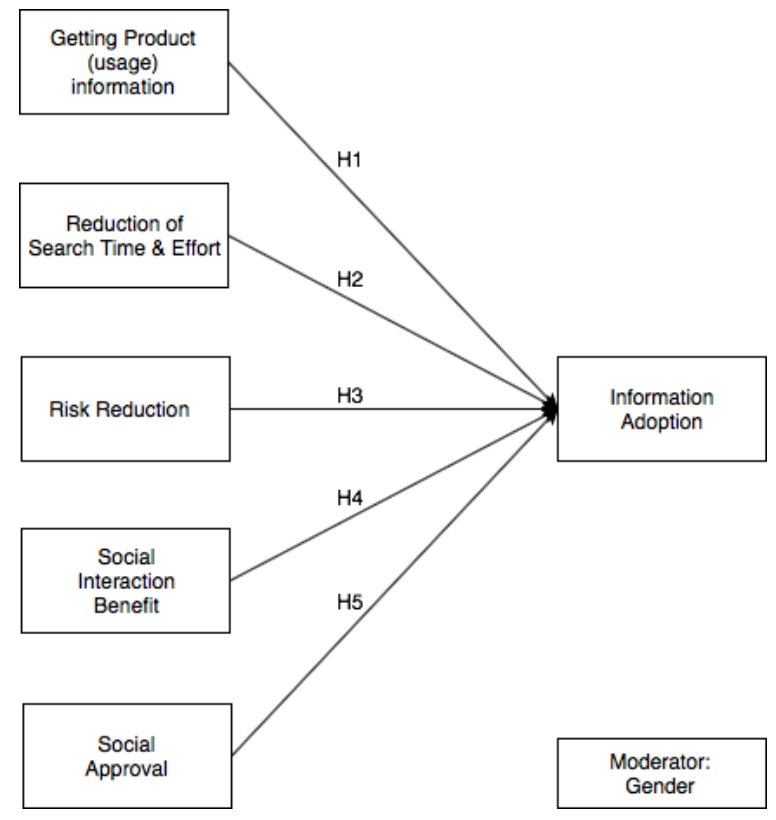

Figure 1 Proposed Research Model

\subsection{Getting product (usage) information}

According to Hennig-Thurau, Walsh and Walsh [20] people seek eWOM information in order to get product-related information. Due to the fact that eWOM is provided by people who bought and used the product, receivers of information find it more relevant in comparison with information provided by companies. Individuals can obtain information about new products and services, solve problems associated with using products/services and learn how to consume the products [23]. Since it was found by previous studies that motivations to seek eWOM can results on consumer's behavior, the following is proposed:

H1: Getting product (usage) information has a positive effect on consumer's information adoption. 


\subsection{Reduction of search time and effort}

Nowadays consumers are faced with a high volume of available information online and a wide range of available products and services. Consumers might, as such, experience difficulties in knowing all the alternatives available to them [24]. eWOM communications can help consumers get the needed buying-related information with a reduction of time on search activities. Researchers investigated that reduction of search time and effort motivates people to receive information using eWOM communications and can influence their behaviour online [6, 20, 25]. As a result, it is proposed that:

H2: Reduction of search time and effort has a positive effect on consumer's information adoption.

\subsection{Risk reduction}

Consumers rely on eWOM communications to minimise the perceived risk associated to making buying decisions [19]. eWOM communications provide individuals with clarification and feedback opportunities and minimise uncertainty before buying and using particular products or services [26]. Researchers found that risk reduction is one of the main motivations for people to receive eWOM communications and that risk reduction also influences consumers' online behaviour [6, 20, 27, 28]. Thus, the following hypothesis is proposed:

H3: Risk reduction has a positive effect on consumer's information adoption.

\subsection{Social interaction benefits}

Previous studies found that social interaction benefit motivates people to seek eWOM communications, as individuals can participate in other consumers' shopping experience and derive a sense of belonging to an online community [20, 21, 28]. Furthermore, it was found that social interaction benefits influence online behaviour [20]. Thus, the following it proposed:

H4: Social interaction benefit has a positive effect on consumer's information adoption.

\subsection{Social approval}

Consumers have a motivation to seek information through eWOM communications to buy products or services accepted by other individuals. Additionally, by using eWOM communications consumers can become aware of a social image of a product or a service, as well as compare their thoughts and opinions about them with other individuals [20, 24]. Researchers on eWOM communications found that social approval plays an important role for people's motivation to look for eWOM of others on Internet $[6,20,29]$. Studies found that social approval can influence consumers' behaviour on Internet [6, 20]. As a result, it is proposed that:

H5: Social approval has a positive effect on consumer's information adoption. 


\subsection{Gender}

Number of studies found that there are gender differences in internet use [30] and information processing [6,31,32]. For example, Bem [31] investigated that men and women use different cognitive attributes for information encoding and problemsolving. Another study conducted by Meyers-Levy [32] found that men focus on concrete, objective cues such as form and physical attributes, while women pay more attention to the message content and react to more subtle cues in messages. Kim, Mattila and Baloglu [6] found that men and women have different motivations to seek eWOM communications. So, based on the previous studies the following hypothesis is proposed:

H6: Gender has a moderating effect on the impact of motivations to seek eWOM on information adoption

\section{Conclusion}

This study aims to develop a conceptual research model in order to examine how motivations to receive eWOM communication affect information adoption based on moderating effect of gender. Through the application of the framework proposed by Hennig-Thurau, Walsh and Walsh [20] this study developed a set of hypotheses which aim to examine how consumer's motivation to receive eWOM influence their information adoption as well as the role gender plays in it. Studying the influence of motivations on information adoption has important implications for both theory and practice. It will improve current state of knowledge of factors affecting information adoption and the impact of gender, which will advance theory of information processing. Thus, it will help researchers to advance the knowledge and understanding of consumer behaviour online. Marketers can use this study to develop better marketing strategies to influence information adoption, which will influence consumers purchase decisions, ultimately resulting in increased sales [33].

The next steps to be undertaken in order to validate the proposed hypotheses will be to collect information online using questionnaires and to apply structural equation modelling to analyse the collected data using the $\mathrm{IBM}^{\circledR}$ SPSS $^{\circledR}$ Amos software.

\section{References}

1. Dimoka, A., Hong, Y., Pavlou, P.A.: On product uncertainty in online markets: Theory and evidence. MIS quarterly 395-426 (2012)

2. Ismagilova, E., Dwivedi, Y.K., Slade, E., Williams, M.D.: Electronic word of mouth (eWOM) in the marketing context: A state of the art analysis and future directions. Springer (2017)

3. Lis, B.: In eWOM we trust. Business \& information systems engineering 5, 129-140 (2013)

4. Teng, S., Wei Khong, K., Wei Goh, W., Yee Loong Chong, A.: Examining the antecedents of persuasive eWOM messages in social media. Online Information Review 38, 746-768 (2014) 
5. Jeong, H.-J., Koo, D.-M.: Combined effects of valence and attributes of e-WOM on consumer judgment for message and product: The moderating effect of brand community type. Internet Research 25, 2-29 (2015)

6. Kim, E.E.K., Mattila, A.S., Baloglu, S.: Effects of gender and expertise on consumers' motivation to read online hotel reviews. Cornell Hospitality Quarterly 52, 399-406 (2011)

7. Bartikowski, B., Walsh, G.: Attitude contagion in consumer opinion platforms: posters and lurkers. Electronic Markets 24, 207-217 (2014)

8. Baber, A., Thurasamy, R., Malik, M.I., Sadiq, B., Islam, S., Sajjad, M.: Online wordof-mouth antecedents, attitude and intention-to-purchase electronic products in Pakistan. Telematics and Informatics 33, 388-400 (2016)

9. Baek, H., Ahn, J., Oh, S.: Impact of tweets on box office revenue: focusing on when tweets are written. ETRI Journal 36, 581-590 (2014)

10. Kim, S.H., Park, N., Park, S.H.: Exploring the effects of online word of mouth and expert reviews on theatrical movies' box office success. Journal of Media Economics 26, 98114 (2013)

11. Aghakhani, N., Karimi, J.: Acceptance of implicit and explicit eWOM: a factor based study of social networking sites. (2013)

12. Hennig-Thurau, T., Gwinner, K.P., Walsh, G., Gremler, D.D.: Electronic word-ofmouth via consumer-opinion platforms: What motivates consumers to articulate themselves on the Internet? Journal of interactive marketing 18, 38-52 (2004)

13. Sussman, S.W., Siegal, W.S.: Informational influence in organizations: An integrated approach to knowledge adoption. Information systems research 14, 47-65 (2003)

14. Cheung, R.: The influence of electronic word-of-mouth on information adoption in online customer communities. Global Economic Review 43, $42-57$ (2014)

15. Shuang, Y.: Effects of information quality and source credibility on EWOM adoption in context of virtual community. In: Management Science and Engineering (ICMSE), 2013 International Conference on, pp. 194-200. IEEE, (Year)

16. Wang, X., Teo, H.-H., Wei, K.K.: SIMULTANEITY AND INTERACTIVITY OF THE EFFECTS OF COMMUNICATION ELEMENTS ON CONSUMERS'DECISION MAKING IN EWOM SYSTEMS. Journal of Electronic Commerce Research 16, 153 (2015)

17. Bansal, H.S., Voyer, P.A.: Word-of-mouth processes within a services purchase decision context. Journal of service research 3, 166-177 (2000)

18. Chang, H.H., Wu, L.H.: An examination of negative e-WOM adoption: Brand commitment as a moderator. Decision Support Systems 59, 206-218 (2014)

19. Goldsmith, R.E., Horowitz, D.: Measuring motivations for online opinion seeking. Journal of interactive advertising 6, 2-14 (2006)

20. Hennig-Thurau, T., Walsh, G., Walsh, G.: Electronic word-of-mouth: Motives for and consequences of reading customer articulations on the Internet. International journal of electronic commerce 8, 51-74 (2003)

21. Khammash, M., Griffiths, G.H.: ‘Arrivederci CIAO. com, Buongiorno Bing. com’Electronic word-of-mouth (eWOM), antecedences and consequences. International Journal of Information Management 31, 82-87 (2011) 
22. Guadagno, R.E., Cialdini, R.B.: Online persuasion: An examination of gender differences in computer-mediated interpersonal influence. Group Dynamics: Theory, Research, and Practice 6, 38 (2002)

23. Bickart, B., Schindler, R.M.: Internet forums as influential sources of consumer information. Journal of interactive marketing 15, 31-40 (2001)

24. Han, S.M.: Motivations for providing and seeking eWOM: a cross cultural comparison of US and Korean college students. ProQuest (2000)

25. Munzel, A., H. Kunz, W.: Creators, multipliers, and lurkers: who contributes and who benefits at online review sites. Journal of Service Management 25, 49-74 (2014)

26. Silverman, G.: Secrets of word-of-mouth marketing: how to trigger exponential sales through runaway word of mouth. AMACOM Div American Mgmt Assn (2011)

27. Awad, N.F., Ragowsky, A.: Establishing trust in electronic commerce through online word of mouth: An examination across genders. Journal of Management Information Systems 24, 101-121 (2008)

28. Burton, J., Khammash, M.: Why do people read reviews posted on consumer-opinion portals? Journal of Marketing Management 26, 230-255 (2010)

29. Huang, L., Shao, J., Wang, W.: Research on the relationships between hotel internet word-of-mouth and customers' behavior intention based on trust. In: Information Management, Innovation Management and Industrial Engineering (ICIII), 2013 6th International Conference on, pp. 250-254. IEEE, (Year)

30. Pope, N., Brown, M., Forrest, E.: Risk, innovativeness, gender, and involvement factors affecting the intention to purchase sport product online. Sport Marketing Quarterly 8, 25-34 (1999)

31. Bem, S.L.: Gender schema theory: A cognitive account of sex typing. Psychological review 88, 354 (1981)

32. Meyers-Levy, J.: The influence of sex roles on judgment. Journal of consumer research 14, 522-530 (1988)

33. Sharma, R., Morales-Arroyo, M., Pandey, T.: The emergence of electronic word-ofmouth as a marketing channel for the digital marketplace. (2012) 